\title{
Using a Vygotskian sociocultural approach to pedagogy: Insights from some teachers in South Africa
}

\section{Edmore Mutekwe}

Northwest University, Faculty of Education,

School of Professional Studies in Education

Email: Edmore.mutekwe@nwu.ac.za/emutekwe@yahoo.com

(Received 22 November 2017; accepted 17 May 2018)

\begin{abstract}
The goal of the study on which this article is based was to examine teachers' perspectives on the effectiveness of adopting a Vygotskian sociocultural approach to teaching and learning in the classrooms. The study used focus group interview discussions to gather views from 20 classroom practitioners who had completed a BEd Hons in Education Psychology. The teachers were from five secondary schools in the Gauteng region. Among the key concepts explored in the focus group discussions (FGDs) were the role of scaffolding when linked to mediated learning experiences (MLEs), the use of situated learning experiences in the learners' zones of proximal development (ZPD), and how the approach helped transform the learners' skills from lower to higher psychological functions through the use of material, psychological and semiotic tools in the classroom. The analysis of the data followed a thematic approach, with emerging codes being clustered into code families. Among the key findings of the study was the view of teachers that adopting a multipronged strategy that includes the use of authentic learning conversations, learning tools (material, psychological, and semiotic) and situated learning experiences goes a long way towards fostering useful teaching and learning. The study illustrated that classroom practitioners do need to take into account and adopt the many and varied benefits that can be derived from an authentic sociocultural approach to teaching and learning.
\end{abstract}

Keywords: scaffolding, learning tools, zone of proximal development, transform

\section{Introduction}

The purpose of this study was to examine how adopting a sociocultural pedagogy in teaching and learning enhances effective classroom interaction and ultimately promotes an equity pedagogy while also catering for diversity. In adopting a qualitative methodology and using focus group discussion as the data collection strategy, this study gathered views from 20 selected experienced socioculturally trained secondary school classroom practitioners in Gauteng, South Africa. Following Wood, Bruner, \& Ross (1976), the study explored the role of scaffolding and linked it to MLEs, the use of situated learning experiences in the learners' zones of proximal development (ZPD). It examined how mediation helps transform the learners' skills into executive functioning through the use of material, psychological, and 
semiotic tools in the classroom. However, although the term scaffolding is not necessarily directed at the dialectical relationship between scientific and everyday concepts and has no specific developmental aspect in terms of Vygotsky's notion of the ZPD, I use it as a Western take on Vygotsky's Soviet psychology.

\section{Problem statement}

The work of John-Steiner and Mahn (2008) on cognitive justice and inclusivity in educational institutions highlights the challenges many classroom practitioners encounter in their quest to provide all learners with equal educational opportunities in schools. In their view, complete inclusion and equality of educational opportunity implies ensuring that learners are treated equally and fairly in their learning institutions. However, this is often lacking in many of the multicultural educational settings the world over (Eisner, 2010). Among the varied challenges many classroom practitioners encounter in promoting complete inclusivity in their classrooms is the lack of ideal strategies to promote equitable learning. Eisner (2010) asserts that it is important to note that the need for learning equity should be articulated not only through human rights declarative documents but also through educational policies and practices for schools. This implies, essentially, advocating for non-discriminatory practices in the school in relation, directly and indirectly, to gender, sex, race, class, socio-economic status, culture, and/or creed (Darling-Hammond, 2012). What many classroom practitioners fail to understand is that equity pedagogy entails not just affording learners' equality of educational opportunity but also ensuring that they are treated justly and fairly in their institutions of learning (Magano, Mostert, \& Van der Westhuizen, 2012). Equitable learning is therefore crucial in all multicultural educational settings if the education system is to ensure that learner diversity is catered for in education.

\section{Theoretical framework}

Contemporary educational practice is based on a paradigm shift from traditional pedagogies to modern progressive constructivist approaches that foster learning equity in the classroom (Kozulin, 2012). Social constructivism as defined by Mutekwe, Machingambi, Maphosa, Ndofirepi, \& Wadesango (2013) is an epistemology that foregrounds the social construction of knowledge through interactive teaching and learning activities in the classroom. It undergirds the importance of knowledge as a product co-constructed by the educators in meaningful interactions with the learners (Mutekwe et al., 2013). The pioneers of this approach to learning and development are Jean Piaget and Lev Vygotsky, whose cognitive and cultural-historical theories respectively laid the foundation for what pedagogists now claim to be formidable epistemologies (Wertsch, 2008). According to Mutekwe et al. (2013) the sociocultural approach to teaching and learning has the advantage of affording virtually all learners in the classroom an opportunity to participate in interactive learning activities since, as Vygotsky (1987) made clear, this approach emphasises drawing from the learners' diverse sociocultural backgrounds. For Kozulin (2012), according to Vygotsky, MLE describes learning situations facilitated by a go-between (mediator) who ensures that the learners understand the content at stake. 
Chaiklin (2003) notes that the term zone of proximal development is probably one of the bestknown ideas associated with Vygotsky's scientific production. It now appears in most developmental and educational psychology literature, as well as in some general psychology textbooks. The concept is now used widely (or referred to) in studies about teaching and learning in many subject areas, including reading, writing, mathematics, science, secondlanguage learning (see Dunn \& Lantolf, 1998), moral education (Tappan, 2012) and violin teaching (Gholson, 2010) with many different kinds of pupils, including so-called disadvantaged, learning disabled, retarded, and gifted ones. It is used with preschool children (see Rieber, 2015) and with adults with information technologies and computer-mediated communication and in discussions about teacher training (Rieber, 2015; Torres, 2016). The concept has also been picked up and used in serious and substantive ways in other academic disciplines and professional areas, including psychoanalysis, psychotherapy, and occupational therapy (Exner, 2010; Lyons, 2011). The term itself describes the distance between the actual developmental level as determined by independent problem solving and the level of potential development as determined through problem solving under adult guidance or in collaboration with more capable peers (Vygotsky, 1978). The term is now being used more often than not in conjunction with scaffolding, a term coined by Wood, Bruner, and Ross (1976). In other words, ZPD has become synonymous in the literature with scaffolding. However, it is important to note that Vygotsky never used this term in his writings. It was introduced by Wood et al. (1976) to imply that once the learner, with the benefit of scaffolding, masters the task, the scaffolding can then be removed, and the learner will be able to complete the task on his or her own.

Chaiklin (2003) further observes that the common conception of the ZPD presupposes an interaction between a more competent person and a less competent one on a task such that the less competent person becomes independently proficient at what was initially a jointly accomplished task. In this general conception, three main aspects-generality assumption (applicable to learning all kinds of subject matter), assistance assumption (learning is dependent on interventions by a more competent other) and potential assumption (properties of the learner that enable best and easiest learning) — are often emphasized (Chaiklin, 2003). The first aspect focuses on the idea that a person is able to perform a certain number of tasks alone but a greater number in collaboration. The range of tasks performed in collaboration is sometimes presented as the definition of ZPD (see Berk, 2017), but this is surely mistaken for even the classic definition refers to levels of development, not tasks. At best, the number or kinds of tasks must be taken as indicators to be interpreted in relation to a level of development. A related issue has to do with what kinds of tasks involve a ZPD. It is often assumed that the ZPD is meant to be applied to any kind of learning task (Tharp \& Gallimore, 2010) or, in an expanded conception formulated by Wells (2015), it applies to any situation in which, while participating in an activity, individuals are in the process of developing mastery of a practice or understanding a topic. The second aspect, assistance assumption, emphasizes how an adult, teacher, or more competent person should interact with a child. Sometimes this aspect is presented as the defining characteristic. Arguably, the notion of the ZPD is little more meaningful than that of a learning situation presented to a child, where adults or more advanced children directly or indirectly have a positive influence on the child (Gillen, 2010). 
The third aspect, potential assumption, focuses on properties of the learner including notions of the learner's potential and or readiness to learn. This aspect often seems to inspire the expectation that it is possible to accelerate or facilitate a child's learning greatly if the zone can be identified properly. For Fabes and Martin (2011), "It is within this zone that a person's potential for new learning is strongest" (p. 42). For LeFrancois (2010), this is Vygotsky's phrase for the individual's current potential for further intellectual development, a capacity not ordinarily measured by conventional intelligence tests. Sometimes this aspect is interpreted to mean that teaching in the ZPD should result in the easiest or most effortless form of learning for the child. As Rieber (2015) puts it, “A student's zone of proximal development is the range of book readability levels that will challenge a student without causing frustration or loss of development [and] is meant to be applied to any kind of learning task (p. 37).

A mediator, for Vygotsky, is therefore not only a human being such as a teacher, parent or more competent peer collaborator but can also be the tool(s) used to enhance learner understanding of the concepts covered in the teaching and learning process (Wertsch, 2008). The concept of mediation is central to the Vygotskian sociocultural perspective. It implies that developmental teaching and learning situations need to be facilitated or mediated in one way or another (John-Steiner \& Mahn, 2008). For Vygotsky (1987), there are different forms of mediators: material; psychological; semiotic; and other human beings. The role of mediation in learning is therefore to transform the learners' skills from lower to higher cognitive functions as the learner progresses from prior to new knowledge forms (Kozulin, 2012). Mediated learning experiences thus describe scaffolded learning activities during which learners are taken through the paces (de Valenzuela, 2009; Wertsch, 2008). The objective of all forms of mediation is to ensure that every function in the learner's cultural development appears thrice-first, on the social level, and later on the individual level or between people (inter-psychological), and then inside the learner (intra-psychological; de Valenzuela, 2009; Vygotsky, 1978). This is the perspective of this study.

\section{Aims of the study}

The study aims to explore teachers' perspectives on how adopting a Vygotskian sociocultural approach to classroom practice enhances inclusion and contributes towards equitable learning in schools. The study has the following objectives:

- to establish the benefits, if any, of using the sociocultural approach to teaching and learning in the classroom;

- to explore the usefulness of mediation in the learners' ZPDs; and

- to examine the benefits of using learning tools to mediate learning in the classroom.

The following research questions guided the study:

- What benefits does the sociocultural approach to teaching and learning offer for classroom practice? 
- How does mediating learning in the learners' ZPD help in the learning process?

- What role is played by learning tools in mediated learning experiences in the classroom?

\section{Research methodology}

The 20 participants had studied Educational Psychology, which included the Vygotskian sociocultural theoretical framework, at the Bachelor of Education Honours level. Thus, all the participants had a thorough knowledge of how scaffolding learners in their ZPDs ensures that their skills are transformed from lower to higher mental functions (Kozulin, 2012) and knew how to take learner diversity seriously in their classroom practice and effectively mediate the learning situation in the learners' ZPDs. I purposefully sampled from the list of educators I taught in the Bachelor of Education Honours programme and who then taught in schools in the Gauteng province. They were regarded as trained and capable of effectively handling the sociocultural diversity elements of humanity such as race, class, differential ability, different learning conditions and styles, ethnicity, age, gender, sexual orientation, religion, nationality, and other dimensions that make up the identity of individual learners and impact their learning experiences. I adopted a qualitative approach and a case study design involving five coeducational secondary schools in which the social sciences educators were consciously attempting to teach using the principles of both learner diversity and equitable learning.

Data was collected through focus group discussions. Following Babbie and Mouton's (2010) caution regarding participants' proximity to researchers, the five coeducational, secondary schools were located in the townships of Meadowlands, Randfontein, Krugersdorp, Sophiatown, and Orlando to cover the different socioeconomic status of the learners. Each school provided four participants for the study. The participants were asked questions related to the role of learning tools as an aspect of MLEs, the use of learning tools and situated learning experiences in the learners' ZPDs and how mediation helps transform the learners' skills from lower to higher mental functions.

Ethical considerations were followed, including requesting permission from the Gauteng Department of Education, assuring participants of the principles of confidentiality, anonymity, voluntariness of participation and protection from harm, as well as obtaining their informed consent after highlighting the study's objectives to the school personnel who constituted the important gate keepers.

\section{Data analysis}

The analysis of data followed a thematic approach, with emerging codes being clustered into code families or what Nieuwenhuis (2016) calls superordinate themes. The themes emerging from the focus group discussions were the importance of fostering equitable learning in the classroom; improving access to learning through mediated learning experiences in the classroom; scaffolding learning through material, psychological, and semiotic means as well as other human beings; the role of learning conversations or class discussions in enhancing 
equitable learning in the curriculum; how situated learning experiences (SLE) promote equitable learning and how adopting indigenous knowledge systems (IKS) can advance the equitable learning agenda. These themes thus form the basis of the discussion of the findings in the next section of this article.

\section{The importance of fostering equitable learning in the classroom}

In line with the notion of equitable learning as described by van der Westhuizen (2009) and McGee Banks and Banks (2009) as a process of empowering all learners by affording them not only equality of educational opportunity but also ensuring that they receive fair treatment in their educational institutions, many participants argued that through equitable learning many if not all learners will have an opportunity to enjoy parity in their learning processes regardless of race, sex, gender, religion, social class, ethnicity, disability, culture, or creed. This view seemed to resonate with Eisner's (2010) assertion that equitable learning should prevent cultural discrimination. Asked to explain how, as classroom practitioners, they can promote equitable learning, the participants cited integrating all of the learners' sociocultural attributes in the social construction of knowledge, refraining from viewing them as empty vessels, considering them as important partners to their educators in the co-construction of knowledge, adopting equity pedagogies in the school and classrooms, and avoiding the use of stereotypes along such unreasonable grounds as race, sex, age, ethnicity, religion, or disabilities. In their view, ensuring these aspects certainly enhances meaningful learning and improves learning attainment among the learners. These views are shared by DarlingHammond (2012) in her contention that equitable learning as a practice should regard all learners as equals irrespective of their diversities, differences, or handicaps.

\section{Improving access to learning through MLEs in the classroom}

It emerged from the FGDs that 12 of the 20 participants claimed that access to improved learning can be achieved through MLEs that describe scaffolded learning situations during which classroom practitioners need to explain, demonstrate, facilitate, and scaffold learners' skills constantly from lower to higher cognitive functions. For 15 of the 20 participants, mediation should involve the use of learning tools classified as material, psychological, semiotic, and other human beings (Vygotsky, 1987). Consistent with the views of Vygotsky (1978), the objective of the mediation effort would certainly be to ensure that every function in the learner's cultural development appears on the social and, later, on the individual level or between people (inter-psychological) and then inside the learner (intra-psychologically) as described above. The mediation process thus needs to occur when learners desperately need to develop the psychological tools with which they can then alter their lived experiences thus establishing the dialectical link between every day and scientific processes (Chaiklin, 2003). 


\section{Scaffolding learning through material, psychological, semiotic means, and other human beings}

According to the views of 11 of the 20 participants, it is clear that tool-mediated learning experiences enable the learners' lower psychological functions to be transformed into higher psychological ones as participant 8 explained.

Sometimes when as educators we use material tools to demonstrate mathematical concepts, for example using the abacus to demonstrate place value, our learners master the concept pretty well and can then use that mastery to develop a further understanding of the link of position values in multiplication, division or even addition and subtraction of figures.

Of the 20 participants, 13 noted that if carried out within the learners' place of potential development, the mediation or facilitation process is highly likely to yield heavy dividends in the learners themselves. These sentiments resonate with those of Wertsch (2008) who notes that mediating learning in the learners' ZPD takes into account that every individual learner is perfectly able to achieve more with the help of a mediator. It was at this stage that I noted that although this needed to be proven not through FGDs but through engagement on objective tasks, Vygotsky's double stimulation methodology, although not used here, would have worked well.

Asked to exemplify the material tools used in their classrooms in the teaching and learning of different subjects, participants cited flash cards, lecture slides, transparencies, posters, wall charts for language teaching, abacuses, number line charts, multiplication and division charts for mathematics, worksheets, and all other teaching and learning media such as computers and digital gadgets like calculators and smart phones used to enhance learner understanding of concepts in the classroom. This view lends credence to Tudge's (2010) assertion that any physical artefacts (teaching aids) that classroom practitioners employ to enhance learner understanding in the classroom can be regarded as learning tools. A specific category of learning tools identified by the participants as crucial in MLEs are what Vygotsky (1987) termed psychological tools. Although the participants used the terms teaching and learning aids and did not describe the learning tools as theoretically as did Vygotsky, the fact that the examples they cited included common types such as gestures, counting fingers, casting lots, semiotics, and other discourse markers shows that they valued the use of physical and psychological artefacts in the teaching and learning process. No wonder proponents of the Vygotskian sociocultural approach to learning and development (for example, Hardman, 2004; John-Steiner \& Mahn, 2008; Kozulin, 2012; Wertsch, 2008) maintain that the learners' higher mental processes are functions of mediated learning activities. This implies that, for example, through language or discourses, gestures and counting fingers as used in scaffolding learning, the learners' knowledge base is transformed to a higher or superior level and this constitutes efficient and effective learning in the curriculum. Participant 10 illustrates this viewpoint. 
When I use teaching and learning aids such as individual and group worksheets in for example teaching sentence construction in essay writing skills, my learners can easily master and their learning improves from constructing individual sentences to constructing sensible paragraphs. I can actually see that the learners' skills have improved from a lower to a higher level.

\section{The role of learning conversations in enhancing equitable learning in the curriculum}

Of the participants, 10 also pointed out that learning conversations as verbal social interactions in the school and classroom have the potential to foster equitable learning. Asked to give examples of how this can occur in the classroom in different subjects, they cited class discussions, group discussions, seminars, debates, role plays, and/or drama. Such conversations mediated by the classroom practitioner thus need to be implemented in the classrooms if the learners from the diverse sociocultural backgrounds are to be assisted to enjoy learning equity and the benefits of true inclusivity. Participant 11 had the following to say in relation to the role of learning conversations in fostering equitable learning.

The current pedagogical thrust especially in the South African context of schooling is for educationists to embrace learning conversations or dialogic multi-cultural educational practices in the interest of complete inclusivity in the educational classrooms.

Carefully thought-out learning conversations in the school and classroom can go a long way towards promoting the goal of equitable learning. Some of the participants claimed that learning conversations are certainly among the most effective strategies for achieving inclusivity and equitable learning in schools. Their argument centred on the view that through such approaches they are able to provide their diverse learners with the support base necessary for them to feel equally empowered with a strong sense of belonging so, when motivated enough, they will then not only be able to do their best academically but will also start believing in themselves which will then culminate in their being able to motivate others to follow suit. For Wertsch (2008) this is in tandem with the premise that learning through chalk and talk awakens a variety of internal developmental processes that can operate when the learners interact. Kozulin (2012) adds that it is in such interactions that the learners coconstruct knowledge with their classroom practitioners as mediators.

\section{How situated learning experiences (SLEs) promote equitable learning in the curriculum}

Of the 20 participants, 14 noted that whenever learning activities are located within familiar experiences, the chances are that learners enjoy learning and maximize the benefits thereof. For 11 participants one of the important ways through which diverse classrooms can become learning communities in which each participant makes significant contributions to the 
emergent understandings and knowledge of all members, despite having different backgrounds, is through social interactive activities involving the use of the learners' everyday experiences as the building blocks for their motivation. In my view, such an understanding resonates with that of Lave and Wenger (1998), who have put forward an interesting account of how locating learning activities in socially interactive activities helps learners develop some degree of social cohesion, which they describe as communities of practice. Similar views are echoed by Brown, Collins, and Duguid (2009) in their discussion of reciprocal teaching, an approach in which learners and their educators take turns leading discussions about shared texts to foster structured dialogues and authentic learning communities of practice. For Brown et al. (2009) such an approach enables positive conceptual changes in both the learners and their educators as they begin to share welldefined tasks through questioning, clarifying, summarizing, and predicting issues with each other in order, for example, to co-construct text-based knowledge. These approaches thus exemplify two themes in the sociocultural approach to classroom learning and development: the implementation of an educational program that allows for or encourages the coconstruction of knowledge; and the analysis of a learning programme that contributes to an understanding of classroom learning from a sociocultural point of view (John-Steiner \& Mahn, 2008).

For 16 of the 20 participants experiential learning appears to offer important insights into their learners especially when compared with the lecture method they sometimes adopt. Asked to elaborate on this view, these participants argued that this means, essentially, that their learners learn better through the sensory experiences of sight, feelings, touch, smell, and hearing as well as experimentation, trial and error, independent observation of nature and human behaviour, and voluntary community sharing of information, story, song, and ritual, among others. This lends credence to assertions by Pablo and Ragoff (2012) that in many modernized societies, situated learning experiences often refer to learners operating in a variety of ways, including free play or interaction with other multi-ethnic, multi-racial, or multi-religious learners, immersing themselves in and directly helping each other with work and communal activities. Further to this, other proponents of the situated learning approach to learning and development, (see Black, 2012), maintain that once learning is institutionalized and alienated from the learners' everyday experiences, both the freedom of the individual and his or her respect for the elder's wisdom are ruined. Additionally, as Black notes, when this occurs, family and community are side-lined as the classroom practitioner assumes all control over the learner.

\section{How adopting IKS can advance the equitable learning agenda}

Adopting IKSs, as 12 participants pointed out, is one way through which the promotion of the equitable learning agenda can be enhanced. In unpacking this argument one dominant view, as expressed by participant 18 , emerged. 
The teaching and learning of IKSs ensure that the traditional knowledge, models, beliefs, norms, values, methods, and content are imparted within the formal educational systems to the satisfaction of virtually all learners.

This is consistent with the view of Semali and Kincheloe (2009) who contend that the growing recognition and use of indigenous education knowledge and methods can be a vehicle for promoting learner inclusivity and equity in education. Asked to further elaborate on this view, participant 19 argued that adopting IKSs in educational institutions is, and should be, a worthwhile response to the erosion and loss of the IKSs as a consequence of the processes of colonialism, globalization, and modernity. It is clear that adopting IKSs in the school curriculum has the potential to make indigenous communities reclaim and revalue their socio-cultural traditions, languages, beliefs, attitudes, and values and in so doing, improve the educational success of all learners, thus ensuring their respect, survival and integration into the global culture. Aikman (2003) and Sha (2014) have contended that using collaborative learning experiences is essential because the learners' IKSs are used as prior learning experiences worthy of recognition as part of the lower psychological functions to be transformed to higher ones through MLEs. For them this has the potential to go a long way towards increasing the learners' desire for more interactive classrooms. The same view is shared by Odora-Hoppers (2011) and Magano et al (2012) who have claimed that for educators to promote equitable learning through pedagogy, the learning conversations to be adopted need to draw from the learners' IKSs so as to bring their existing IKS backgrounds into the co-construction of new forms of knowledge in line with the constructivist approaches emphasized in today's teaching and learning paradigms (van der Westhuizen, 2012; Wertsch, 2008). This dovetails with assertions by Pablo and Rogoff (2012) that where indigenous knowledge learning tools are used to mediate learning, the potential for social harmony is higher than where unfamiliar learning tools are employed.

Ten participants (50\% of the total sample) claimed that the IKSs and indigenous learning styles often included observation, imitation, use of narrative or storytelling, collaboration, and cooperation as seen among African, American, Indian, Alaska Natives, and Latin American communities and therefore, if adopted in the classroom in line with the tenets of the sociocultural approach, this form of hands-on emphasising of direct experience and learning through inclusion has the potential to go a long way towards fostering the equitable learning agenda. This view resonates with those of Deyhle and Swisher (2007) who concluded in one of their studies that such a learning approach enables learners to feel that they are vital members of the wider school community. Black (2012) also added that it encourages them to participate in a meaningful way as important community members. Fourteen participants argued that in many traditional educational societies, children often learn skills this way without being taught explicitly or in a formal manner and this may differ from Western learning styles, which tend to include methods such as explicit instruction, testing, and quizzing. This view is in line with that of Wilson (2011) who believes that creating an educational environment that is consistent with the learners' upbringing and the need for equitable learning, rather than advocating an education that strictly follows a traditionally Western format, allows for learners to retain knowledge more easily because 
they are learning in a way that recognizes them as equals in society and this has huge potential to yield success for them (Mutekwe, 2014; Verna, 2011). Findings reported here show clearly that despite the contention by researchers such as Felder (2010) that there is nothing in the twentieth century that deserves to be called a learning style, the styles of learning learners use best are the ones typical of their indigenous learning systems or those that occur in the context of their community (May \& Aikman, 2003; Rohrer \& Pashler, 2012).

Fifteen participants claimed that effective classrooms modelled along the principles discussed above should focus typically on group or cooperative learning strategies that provide an inclusive learning environment. According to these participants, a key factor for successful equitable learning through integrating IKS educational practices is the kind of learnereducator relationship that is socially constructed in a way that allows the classroom practitioner to share control of the classroom with the learners. This echoes the UNESCO (2012) view that rather than taking an authoritative role, the classroom practitioner should be viewed as a co-learner by the learners and that both need to maintain a balance between personal warmth and the demands for academic achievement. For example, in such a classroom, learners should be encouraged to use group work activities and be allowed to move freely about the classroom while working in order to consult with other learners. Of the participants, nine (45\%) were unanimous that for indigenous learners and instructors the inclusion of these methods into the curriculum often enhances educational effectiveness by providing an education that adheres to an indigenous person's own perspectives, experiences, language, and customs, thereby making it easier for children to transition into the realm of adulthood. This is consistent with the views of Cornel (2002) and UNESCO (2012) that for non-indigenous learners and classroom practitioners, an education system that promotes equitable learning often has the effect of raising awareness of individual and collective traditions surrounding indigenous communities and people in general, thereby promoting greater respect for and appreciation of various cultural realities. Duane (2009) and Wilson (2011) agree in noting that in terms of educational content, the inclusion of IKSs in curricula, instructional materials, and textbooks has, largely, the same effect on preparing learners for the greater world as other educational systems, such as the Western models. Drawing on the above, one is left with no choice but to infer that what proponents of IKSs such as OdoraHoppers (2011) and Sefa and Rosenberg (2010) assert about the structure of classrooms is meant to promote equitable learning by integrating IKS needs so as to eliminate the distinction between the community and classroom and thus make it easier for the learners to relate to the material aspects of their lives.

\section{Conclusion}

The findings reported here show clearly that it is of utmost importance that equitable learning be fostered in the classroom and that this can be done through MLE in the learners' ZPDs where learning needs to be scaffolded through learning tools (material, psychological, and semiotic as well as other human beings). The findings show that class discussions play an important role in mediating the learning experiences essential to following the curriculum. In 
addition, SLEs also help promote equitable learning especially coupled with IKSs. Many participants believe that there is value in integrating IKSs in education in the public schooling system since this benefits learners of all backgrounds. Participants noted that these strategies can contribute enormously to reducing such social ills as racism, sexism, tribalism, regionalism, and even nepotism in the classroom thereby increasing a sense of community in a diverse world.

\section{References}

Aikman, S. (2003). Indigenous education: Addressing current issues and developments. Comparative Education, 39(2), 139-145.

Babbie, E., \& Mouton, J. (2010). The practice of social research: A South African perspective. Oxford, UK: Oxford University Press.

Berk, L. (2017). Child development (4th ed.). Boston, MA: Allyn \& Bacon.

Black, C. (2012). Occupy your brain: On power, knowledge and the re-occupation of common sense. Retrieved from http://schoolingtheworld.org/blog/occupy/

Brown, J., Collins, P., \& Duguid, D. (2009). Situated cognition and the culture of learning. Educational Researcher, 18(1), 32-42.

Chaiklin, S. (2003). The zone of proximal development in Vygotsky's analysis of learning and instruction. In A. Kozulin, B. Gindis, V. Ageyev, \& S. Miller (Eds.), Vygotsky's educational theory and practice in cultural context (pp. 67-71). Cambridge, UK: Cambridge University Press.

Cornel, P. (2002). Learning styles of American Indian/Alaska Native students: A review of the literature and implications for practice. Journal of American Indian Education, $41(3), 13-17$.

Darling-Hammond, L. (2012). The right to learn and the advancement of teaching: Research, policy and practice for democratic education. Educational Researcher, 25(6), 5-17.

De Valenzuela, J. (2009). Socio-cultural views on learning: The SAGE handbook of special education. London, UK: SAGE.

Deyhle, D., \& Swisher, K. (2007). Research in American Indian and Alaska native education: From assimilation to self-determination. Review of Research in Education, 22, 113194.

Duane, C. (2009). Contemporary education. New York, NY: SAGE. 
Dunn, W. E., \& Lantolf, J. P. (1998). Vygotsky's zone of proximal development and Krashen's “ i + 1": Incommensurable constructs; incommensurable theories. Language Learning, 48, 411-442.

Eisner, T. (2010). Understanding learning equity in a classroom setting. Journal of Social Sciences, 8(6), 119-127.

Exner, C. E. (2010). The zone of proximal development in in-hand manipulation skills of non-dysfunctional 3- and 4-year-old children. American Journal of Occupational Therapy, 38, 446-451.

Fabes, R., \& Martin, C. L. (2011). Exploring development through childhood. Boston, MA: Allyn \& Bacon.

Felder, R. M. (2010). Are learning styles invalid? Nottingham, NC: North Carolina State University Press.

Gholson, S. A. (2010). Proximal positioning: A strategy of practice in violin pedagogy. Journal of Research in Music Education, 46, 535-545.

Gillen, J. (2010). Versions of Vygotsky. British Journal of Educational Studies, 48, 183-198.

Hardman, J. (2004). An exploratory case study of computer use in a primary school mathematics classroom: New technology, new pedagogy. Perspectives in Education, 23(4), 1-12.

John-Steiner, V., \& Mahn, H. (2008). Sociocultural approaches to learning and development: A Vygotskian framework. Educational Psychologist, 34, 113-115.

Kozulin, A. (2012). Psychological Tools. A Sociocultural Approach to Education. Cambridge, MA: Harvard University Press.

Lave, J., \& Wenge, W. (1998). Situated learning: Legitimate peripheral participation. New York, NY: Routledge

LeFrancois, G. (2010). Of children: An introduction to child and adolescent development. Belmont, CA: Wadsworth

Lyons, B. G. (2011). Defining a child's zone of proximal development: Evaluation process for treatment planning. American Journal of Occupational Therapy, 38, 446-451.

Magano, M., Mostert, P., \& Van der Westhuizen, G. (2012). Learning conversations: The value of interactive learning. Johannesburg, South Africa: Heinemann.

May S., \& Aikman, S. (2003). Indigenous education: Addressing current issues and developments. Comparative Education, 3(1),139-145. 
McGee Banks, C., \& Banks, J. (2010). Multi-cultural education in a modern classroom. Journal of Educational Psychology, 3(1), 61-73.

Mutekwe, E. (2014). Unpacking Student feedback as a basis for metacognition and mediated learning experiences: A socio-cultural perspective. Journal of Education and Learning, 8(4), 338-349.

Mutekwe, E., Machingambi, S., Maphosa, C., Ndofirepi, A., \& Wadesango, N. (2013). A SWOT analysis of the rise of the social constructivist epistemology and its pedagogical implications in educational practice. The Anthropologist: International Journal of Studies of Man, 15(1), 53-65.

Nieuwenhuis, J. (2016). Analysing qualitative data. In K. Maree (Ed.), First steps in research (pp. 78-82). Pretoria, South Africa: van Schaik.

Odora-Hoppers, C. (2011). Indigenous knowledge systems and academic institutions in South Africa. Perspectives in Education, 19(1), 73-85.

Pablo, C., \& Rogoff. P. (2012). Schooling and traditional collaborative social organization of problem solving by Mayan mothers and children. Developmental Psychology, 38(1), $55-66$.

Rieber, R. W. (Ed.). (2015). The collected works of L. S. Vygotsky: Vol. 6. Scientific Legacy. (J. M. Hall, Trans.). New York, NY: Academic Press.

Rohrer, D., \& Pashler, H. (2012). Learning styles: Where is the evidence? Medical Education, 46, 634-635.

Sefa, D., \& Rosenberg, D. (2010). Indigenous knowledge in global contexts: Multiple readings of our world. Toronto, Canada: University of Toronto Press.

Semali, L., \& Kincheloe, J. (2009). What is Indigenous Knowledge? New York, NY: Falmer.

Sha, Y. (2014). Learning in adulthood: A comprehensive guide. San Francisco, CA: JosseyBass.

Tappan, M. B. (2012). Moral education in the zone of proximal development. Journal of Moral Education, 27, 141-160.

Tharp, R., \& Gallimore, R. (2010). A theory of teaching as assisted performance. In D. Faulkner, K. Littleton, \& M. Woodhead (Eds.), Learning relationships in the classroom (pp. 93-109). London, UK: Routledge.

Torres, M. N. (2016). Teacher-researchers in the zone of proximal development. Insights for teacher education. Paper presented at the International Conference: A Cultural Historical Approach to the Study of Education: Centenary of Lev S. Vygotsky. Moscow. 
Tudge, J. (2010). Vygotsky, the zone of proximal development and peer collaboration: Implications for classroom practice. In L.C. Moll (Ed.), Vygotsky and Education (pp. 207-215). Cambridge, UK: Cambridge University Press.

UNESCO, (2009). Learning and knowing in Indigenous societies today (Eds., P. Bates, M. Chiba, S. Kube, \& D. Nakashima). Paris, France: UNESCO.

Van der Westhuizen, G. (2012). Learning equity in a university classroom. South African Journal of Higher Education, 26(3), 623-637.

Verna, C. (2011). Silencing aboriginal curricular content and perspectives through multiculturalism: There are other children here. Review of Education, Pedagogy and Cultural Studies, 33(4), 306-317.

Vygotsky, L. S. (1987). Mind in society: The development of higher psychological processes. Cambridge, MA: Harvard University Press.

Vygotsky, L. S. (1978). Learning and mental development at school age. In B. Simon \& J. Simon (Eds.), Educational psychology in the U.S.S.R. (pp. 21-34). London, UK: Routledge.

Wells, G. (2015). Dialogic inquiry: Towards a sociocultural practice and theory of education. Social Work Research, 19(1), 33-37.

Wertsch, J. (2008). From social interaction to higher psychological processes: A clarification and application of Vygotsky's theory. Human Development, 51, 66-79.

Wilson, T, (2011). Best practices for teaching aboriginal children: From an aboriginal and non-aboriginal perspective. Australian Journal of Education, 17(4), 119-123.

Wood, D., Bruner, J., \& Ross, G. (1976). The role of tutoring in problem solving. The Journal of Child Psychology and Psychiatry, 17(2), 89-100. 